\title{
IN MEMORY OF ARKADIUSZ PEISERT
}

Arkadiusz Peisert, assistant professor at the Institute of Sociology of the University of Gdańsk, died on 13 November 2019 in Gdańsk. He was a valued researcher on cooperatives and civil society, a solid scholar, and a colleague with a great sense of humour. He was a graduate of interdepartmental individual humanist studies at the University of Warsaw and defended his doctorate in sociology at the UW Institute of Applied Social Sciences. He then moved to the University of Gdańsk, where he worked in the Department of General Sociology and next in the Department of Sociological Theory and Social Science Methodology.

He was an outstanding sociologist of law and of civil participation. His significant body of scholarly work contains publications of a quite varied nature, from in-depth empirical studies such as "Spółdzielnie mieszkaniowe: pomiędzy wspólnotą obywatelską a alienacją" [The housing cooperative: Between the civil community and alienation] to theoretical essays such as "Społeczeństwo obywateli? Obywatelskość w procesie cywilizowania" [A civil society? Citizenship in the civilising process], inspired by Norbert Elias's book. The latter essay contains many valuable pointers on how organisational mechanisms can further the resolution of difficult social conflicts and the healing of deep divisions. It is thus particularly worth recommending to contemporary politicians, managers, and local government officials.

Arkadiusz Peisert was the author of numerous articles and expert reports and was engaged in the academic life of many institutions, associations, and discussion clubs. He was active in the Gdańsk branch of the Polish Sociological Society and in the European Sociological Association, where he was a member of the board for the Research Network "Sociology of Transformations: East and West." Among his many other activities, his work as a member of the editorial board of Stan Rzeczy should be men- 
tioned. He was one of the group that established the journal. He passed away before he could bring many of his creative ideas and scholarly projects to completion. He was always a helpful, sociable, and trustworthy person. It is very hard for his friends, colleagues, and students to come to terms with his death. 